\title{
Externalities of Colleagues' Human Capital Accumulation and Individual Wages: Empirical Evidence from the Malaysian Service Sector
}

\author{
Noor Fazlin Mohamed Noor \\ Faculty of Management and Economics, Sultan Idris Education University \\ 35900 Tanjung Malim, Perak, Malaysia \\ Zainizam Zakariya (Corresponding author) \\ Faculty of Management and Economics, Sultan Idris Education University \\ 35900 Tanjung Malim, Perak, Malaysia \\ E-mail: zainizam@fpe.upsi.edu.my
}

Norimah Rambeli@Ramli

Faculty of Management and Economics, Sultan Idris Education University 35900 Tanjung Malim, Perak, Malaysia

\section{Azila Abdul Razak}

Faculty of Management and Economics, Sultan Idris Education University 35900 Tanjung Malim, Perak, Malaysia

Received: February 20, 2017 Accepted: March 15, 2017 Published: April 05, 2017 doi:10.5296/ijhrs.v7i1.10789 URL: http://dx.doi.org/10.5296/ijhrs.v7i1.10789

\begin{abstract}
The aim of this study is to examine the extent to which colleagues' human capital accumulation (education, work experience and training) had an impact on individuals' earnings in the service sector in Malaysia. The study employed data from the 2007 Productivity Investment Climate Survey (PICS) and the colleagues' human capital


accumulation was measured using information from both workers and employers survey. Random Effect (RE) was used to estimate the effects of these factors on wages. Findings from the RE showed that only co-workers' education had a positive and significant impact on individual wages. One year of colleagues' additional schooling will increase the individuals' earnings between 2.8 and 4.7 percent a year. Women experience a higher wage premium than that of men (4.7 against 3.5 percent). In addition, educational dispersion between respondents and workplaces also had a significant impact on earnings as it increases workers' earnings between 2 and 3.7 percent for every additional increase of one standard deviation of the educational dispersion. These positive effects can be interpreted as the existence of positive spillovers or externalities of the education of colleagues at the workplace as it can enhance productivity of other employees in the same organization.

Keywords: Externalities, Spill over, Human capital, Co-workers, Wages, Malaysia

\section{Introduction}

Research on the impact of education on individual wages has been widely carried out in developed countries as well as developing countries (the most famous study was done by Psacharopoulos, 1993; Psacharopoulos \& Patrinos, 2004). A few other related studies have been done in Malaysia (Mazumdar, 1993; Chung, 2003, 2004; Amin \& DaVanzo, 2004; Ragayah, 2005; Rahmah Ismail, 2011; Milanovic, 2006; Zakariya, 2013) In general, these studies found that the rate of individual return on investment from education in developing countries was higher (9-15\%) compared to developed nations (5-10\%). A high premium rate for education in developing countries is linked to an emphasis on primary level education, where the investment cost is low, and these contrasts with developed countries which focus on higher level education with a much higher investment cost (Psacharopoulos \& Patrinos, 2004). Nonetheless, education generally has a positive effect on individual wage and provides an indication of workers' productivity as discussed in the Human Capital Theory (Becker, 2009).

Although education achievement (education level or years of schooling) has a positive link with salary received as mentioned in the Human Capital Theory (Becker, 2009), the reality is that education, on its own, is insufficient for the purpose of increasing individual productivity, as the modern-day worker works as a team and not individually, which was common in the conventional workplace (Idson, 1995; Idson \& Kahane, 2000; Charness \& Kuhn, 2004). A lot of duties at the workplace are completed with the help of colleagues or in group - where you need the skills and expertise of workmates in order to facilitate the tasks given (Schaubroeck, Lam, \& Peng, 2011; Bandiera, Barankay, \& Rasul, 2013; Galegher, Kraut, \& Egido, 2014). This indicates that workers' productivity does not only depend on their own human capital, but it also depends on the level of colleagues' accumulation of human capital at the workplace. Having colleagues with high level of education enables the beneficial transfer and sharing of skills, knowledge and expertise for colleagues with lower level of education and skills. This will create a positive spillover effect or colleagues' education externality in the process of increasing other workers' productivity and provide a positive effect on the 
individual wage growth.

Up to date, there are many studies which focus on the spillover effect of colleagues' education, but these studies have looked into the colleagues' education at state, district or city level. Very few studies have discussed the colleagues' education level in the firm itself and its effect on workers' wages in the same organisation (Battu, Belfield, \& Sloane, 2003; Battu et al., 2004). As such, this study aims to assess the extent to which the spillover affects not only the field of education but also the colleagues' human capital, specifically in terms of the effect of experience and training on individual wage in the same workplace. ${ }^{1}$ To answer this question, the discussion in this paper will be divided into 5 main parts. The second part will look at previous studies on the spill over effects of education and colleagues' human capital on individual wage; this will be followed by the study methodology and the utilised data in part 3. The findings of the study will be discussed in part 4 while part 5 will look at the implications and conclusions.

\section{Colleagues' Wages and Human Capital Externalities}

In general, studies on colleagues' wages and human capital externalities can be classified into two parts. In the first part, the studies tend to focus on the aggregate effect of employee education in the city or region on the individual wage in the same city or region (Rauch, 1993; Acemoglu and Angrist, 2001; Moretti, 2004a, 2004b; Liu, 2007; Isacsson, 2005; Kirby and Riley, 2008).

Rauch (1993) in his study "Productivity gains from geographic concentration of human capital: evidence from cities" in the United States used the average education level and age at the city level as proxy for colleagues' human capital. The study found that cities with a high number of highly-educated residents had a positive effect on individual wage. The higher the education and the resident age, the higher the wage received by the individual. Moretti, (2004a) in his study 'Estimating the social return to higher education: evidence from longitudinal and repeated cross-sectional data" also in the United States compared individual wages with the same characteristics but working in cities with different education levels among the residents. His study found that the education externality had an effect on individual wages. The spillover effect was high for workers with low qualifications compared to workers who graduated from colleges. The increase in college graduates of 1 percent drove the increase in wages as much as 1.9 percent for workers with no high school qualifications compared to 1.6 percent and 0.4 percent respectively for workers with high school qualifications and college qualifications. In another study, Moretti (2004b) in "Workers' Education, Spillovers and Productivity: Evidence from Plant-Level Production Function" found that firms which operated in cities with many university graduate workers were more productive compared to firms operating in the same city but with less number of university graduate workers. However, the firms which had many highly-educated workers also showed an increase in labour production costs.

Liu (2007) in his study 'The external returns to education: Evidence from Chinese cities'

\footnotetext{
${ }^{1}$ Becker (1962) and Mincer (1974) suggested that the individual human capital stock which consists of education, working experience and training play important part in upgrading the individual productivity.
} 
found a positive effect of education at city level on employee wages. His study revealed that the education external return rate at city level was as high as the individual return rate between 4.9 and 6.7 percent using the Ordinary Least Square (OLS) method and between 11 and 13 percent using the Two-Stages Least Square (2SLS). In another study, Munch and Skaksen (2008) in "Human capital and wages in exporting firms" looked at the interaction effects between exports and skilled workers for export firms in Denmark. They found that firms with many skilled workers had a positive effect on the workers' wages. Kirby and Riley (2008) in "The external returns to education: UK evidence using repeated cross-sections" looked at the relationship between the education level of industry workers and individual wage in Britain. They discovered that the individual wage had a positive relationship with the educational achievement of industry workers. The higher the educational achievement, the higher the salary earned. The individual wage will increase between 2.6 and 3.9 percent depending on the model and sample specifications for an increase of one year in an average school year for the industry workers.

On the other hand, a few other studies indicated that there was no spillover effect from the employees' or community education on the individual wage (Acemoglu and Angrist, 2001; Isacsson, 2005; Sand, 2013). For example, Acemoglu and Angrist (2001) in their study in the United States found that there was no significant relationship between the average schooling of workers and individual wage at state level. Isacsson (2005) in "External effects of education on earnings: Swedish evidence using matched employee-establishment data" in Sweden found that the fixed-effect estimation model utilised did not show a positive spillover effect of colleagues' education on other employees' wages. Meanwhile, Sand (2013) in his study "A re-examination of the social returns to education: Evidence from U.S. cities" examined the extent to which education had a spillover effect on employees' wages in some American cities. His findings indicated that generally, the percentage of college graduates in a particular town had no stable influence on individual salary throughout the study period. Education externality had a significant effect in the 1980s but was insignificant during the 1990-2000 period.

In the second part, a section of studies on the spillover effects of colleagues' human capital on the individual wage focused on the organisation itself and not based on the city level aggregate education (Idson, 1995; Idson \& Kahane, 2000; Battu, Belfield, \& Sloane, 2003; Battu et al., 2004). This small section of studies generally indicates that having well-educated and productive workmates at the workplace may also increase other workmates' wages in the same organisation. For example, Idson and Kahane (2000) in "Team effects on compensation: an application to salary determination in the National Hockey League" explored the effects of players' achievement on other players' salaries in the same team in the United States. The study revealed that the players' achievement had a positive significant effect on other players' salaries. Meanwhile, Battu, Belfield and Sloane (2003) explored the extent of colleagues' positive spillover on individual wage in the same organisation in the United Kingdom via "Human Capital Spillovers within the Workplace: Evidence for Great Britain". They found that colleagues' education had a positive effect on other workers' wages in the same firm - an extra year of colleagues' education could increase individual wages up to 3.2 percent in a year. 
The authors also found that individual achievement had no benefit on the person himself/herself if he or she had been working with colleagues with similar qualifications.

In the discussion above, a few aspects need more focus. Firstly, most of the previous studies focused on developed countries such as the United States, UK, Sweden, Norway and Denmark. As such, the study findings are only applicable to developed nations and the employees' education spillover effects could not be generalised in developing countries. Secondly, a majority of the studies only focused on education but did not focus on the two main aspects of other human capital accumulations, which are work experience and training. If the human capital theory (Becker, 2009) states that an experienced and trained individual connects positively with the wage, it is likely that a firm with many trained and experienced workers can provide a positive effect on the individual wage in the same organisation. Thirdly, colleagues' education human capital accumulation is measured based on the proxy for average education at city, region or industry level, and not based on the colleagues' human capital in the workplace. If the city or region is more developed compared to a slower developing city, then the more developed city should have a better human capital accumulation level as compared to the less developed city. This endogeneity issue may arise as an effect of the estimation of human capital spillover return rate as many studies have shown that the existing problem may cause a biased estimate of the true return to co-workers' human capital endowments. These limitations can be minimised in this study as the data utilised enables the level of colleagues' human capital accumulation to be acquired in the same firm. This is because there is available data related to the level of human capital accumulation of all workers at the firms involved.

\section{Data and Research Methodology}

This study utilises the Productivity and Investment Climate Survey (PICS) data published by World Bank Enterprise Survey (WBES), World Bank in 2009. The aim of PICS is to look at the effect of changing investment trends on firms' productivity in the sector of business support services. While the data is already 6 years old, the main advantage of PICS compared to other data available in Malaysia is that PICS 2007 focused on two types of survey which are employer survey and employee survey. Employer survey aims to obtain data related to employees' human capital stock (education and number of employees involved in training during working hours), employees' age as well as information about ownership, employee size, products, labour productivity and costs and profits. On the other hand, employee survey aims to look at the demographic background, human capital stock, wages and salary, skills and training and other details. For the employee data, 10 workers were chosen randomly for every firm to be interviewed.

By combining both surveys, data related to work experience, individual education level, respondent training and colleagues' character at the workplace could be identified for every firm. The sample consisted on 303 firms with 2,910 respondents. However, this study only focused on respondents between 15 - 64 years old, respondents who stated their monthly wages and firms with 10 respondents. The respondents who were eliminated included 4 who exceeded 64 years old and 122 respondents with no income data. Firms with less than 10 
respondents were also eliminated (involving 114 respondents and 36 firms). As such, only 2670 respondents (267 firms) were involved in the final analysis.

Table 1: Respondent characteristics for selected variables

\begin{tabular}{|c|c|c|c|c|c|c|}
\hline & \multicolumn{2}{|c|}{ All } & \multicolumn{2}{|c|}{ Male } & \multicolumn{2}{|c|}{ Female } \\
\hline & Mean & $\begin{array}{l}\text { Standard } \\
\text { deviation }\end{array}$ & Mean & $\begin{array}{l}\text { Standard } \\
\text { deviation }\end{array}$ & Mean & $\begin{array}{l}\text { Standard } \\
\text { deviation }\end{array}$ \\
\hline \multicolumn{7}{|l|}{ Human capital characteristics } \\
\hline Age & 33.70 & 8.904 & 34.86 & 9.38 & 32.55 & 8.25 \\
\hline Years of complete schooling $\left(S_{\mathrm{i}}\right)$ & 13.26 & 2.992 & 12.92 & 3.25 & 13.60 & 2.68 \\
\hline \multicolumn{7}{|l|}{ Highest level of education } \\
\hline Degree & 0.35 & & 0.34 & & 0.36 & \\
\hline Diploma & 0.24 & & 0.21 & & 0.28 & \\
\hline Higher secondary & 0.29 & & 0.29 & & 0.29 & \\
\hline Lower secondary & 0.08 & & 0.12 & & 0.05 & \\
\hline Primary school & 0.03 & & 0.05 & & 0.01 & \\
\hline Informal & 0.00 & & 0.00 & & 0.00 & \\
\hline None & 0.00 & & 0.00 & & 0.00 & \\
\hline \multicolumn{7}{|l|}{$\begin{array}{l}\text { Have you attended training at current } \\
\text { workplace }\left(T_{\mathrm{i}}\right)\end{array}$} \\
\hline Yes & 0.57 & & 0.59 & & 0.56 & \\
\hline No & 0.43 & & 0.41 & & 0.44 & \\
\hline Years of working experience $\left(E x p_{\mathrm{i}}\right)$ & 14.43 & 10.186 & 15.93 & 10.91 & 12.95 & 9.18 \\
\hline \multicolumn{7}{|l|}{ Demographic Characteristics } \\
\hline \multicolumn{7}{|l|}{ Gender } \\
\hline Male & 0.50 & & & & & \\
\hline Female & 0.50 & & & & & \\
\hline \multicolumn{7}{|l|}{ Marital status } \\
\hline Single & 0.40 & & 0.37 & & 0.44 & \\
\hline Married & 0.58 & & 0.62 & & 0.55 & \\
\hline Separated (widower/widow) & 0.01 & & 0.01 & & 0.01 & \\
\hline \multicolumn{7}{|l|}{ Race } \\
\hline Bumiputera & 0.49 & & 0.54 & & 0.46 & \\
\hline Chinese & 0.40 & & 0.35 & & 0.46 & \\
\hline Indian & 0.09 & & 0.10 & & 0.07 & \\
\hline Others & 0.02 & & 0.01 & & 0.01 & \\
\hline \multicolumn{7}{|l|}{ Region (reg) } \\
\hline Middle & 0.73 & & 0.71 & & 0.75 & \\
\hline North & 0.10 & & 0.10 & & 0.11 & \\
\hline South & 0.07 & & 0.08 & & 0.06 & \\
\hline East Malaysia & 0.10 & & 0.11 & & 0.09 & \\
\hline \multicolumn{7}{|l|}{ Job characteristics } \\
\hline Job & & & & & & \\
\hline
\end{tabular}




\begin{tabular}{|c|c|c|c|c|c|c|}
\hline Management & 0.16 & & 0.13 & & 0.19 & \\
\hline Professional & 0.32 & & 0.34 & & 0.31 & \\
\hline Skilled worker & 0.23 & & 0.25 & & 0.20 & \\
\hline Unskilled worker & 0.11 & & 0.16 & & 0.07 & \\
\hline Clerical & 0.17 & & 0.12 & & 0.23 & \\
\hline Firm tenure (year) & 6.92 & 6.503 & 7.16 & 6.66 & 6.68 & 6.34 \\
\hline Working hours (week) & 42.55 & 11.900 & 44.23 & 12.26 & 40.89 & 11.30 \\
\hline Salary (monthly) & 2827.26 & 236.977 & 2962.69 & 125.63 & 2693.03 & 212.47 \\
\hline \multicolumn{7}{|l|}{ Industry } \\
\hline Information technology & 0.13 & & 0.13 & & 0.14 & \\
\hline Telecomnunications & 0.04 & & 0.02 & & 0.05 & \\
\hline Accounting & 0.37 & & 0.36 & & 0.38 & \\
\hline Advertising & 0.09 & & 0.09 & & 0.09 & \\
\hline Business Logistics & 0.37 & & 0.40 & & 0.35 & \\
\hline \multicolumn{7}{|l|}{ Firm size } \\
\hline Small ( $<50$ workers $)$ & 0.57 & & 0.60 & & 0.54 & \\
\hline Medium (50 - 150 workers) & 0.28 & & 0.28 & & 0.29 & \\
\hline Big (> 150 workers) & 0.15 & & 0.13 & & 0.16 & \\
\hline \multicolumn{7}{|l|}{ Ownership } \\
\hline Entirely local & 0.81 & & 0.82 & & 0.81 & \\
\hline Less than $30 \%$ of foreign ownership & 0.03 & & 0.04 & & 0.03 & \\
\hline More than $30 \%$ of foreign ownership & 0.15 & & 0.15 & & 0.16 & \\
\hline
\end{tabular}

Table 1 shows the respondents' characteristics (mean and standard deviation) and a few selected variables in this study. Generally, the mean age for the respondents was 34 years old with the mean respondents' schooling period exceeding 13 years. About 60 percent of the respondents had advanced qualifications (diploma and degree) and a majority of them had attended training provided by their employees at the workplace $(57 \%)$ with the average working experience of 14 years. In terms of the demographic aspects, more than half of the respondents were married (58\%), with Bumiputera representing almost 50\% of the sample, while $36 \%$ resided in the west of Peninsular Malaysia. In terms of work, almost $50 \%$ of the respondents worked in upper level (professional and management); followed by skilled workers $(23 \%)$. Generally, the respondents had been working at the current firms (tenure) for almost 7 years and had also worked 43 hours per week with a monthly salary (excluding allowance) exceeding RM2,800. More than $70 \%$ of the respondents worked in two main industries which are accounting and logistics, and more than $80 \%$ worked in small and medium firms and in locally-owned firms. Female respondents were younger but had slightly higher qualifications than male respondents. However, male respondents were more skilled and experienced compared to female respondents. The demographic backgrounds were not much different for both males and females. There were more females working in upper level management while males tended to work as skilled workers. The monthly income was higher for males and this may indicate the longer working hours for males compared to females. Other characteristics were the same for both groups. 
As explained earlier, the main advantage of PICS is that colleagues' human capital endowments (education, working experience and training) are measured in the firm itself using two methods. Firstly, the average human capital stock for the respondents in all firms were based on the respondents' survey data $\left(H C_{\mathrm{r}}\right)$. Secondly, the human capital stock was calculated based on all the workers in every firm based on the employers' survey data $\left(H C_{\mathrm{j}}\right)^{2}$ Table 2 shows the colleagues' human capital characteristics at the workplace. Generally, there was not much difference in value for $H C_{\mathrm{i}}$ and $H C_{\mathrm{j}}$. The overall average schooling for the respondents in every firm $\left(E_{\mathrm{r}}\right)$ was almost the same with the overall average schooling for all workers in every firm $\left(E_{\mathrm{j}}\right)$ (13.5 compared to 13.3 years) while $\operatorname{Exp}_{\mathrm{r}}$ at 14.64 was almost the same with $\operatorname{Exp}_{\mathrm{i}}$ (14.43). Meanwhile, the average age of every worker in every firm, $A g e_{\mathrm{j}}$ was consistent with the respondent age, at 35 years. Nevertheless, the involvement of workers in training was much higher for $T_{\mathrm{r}}$ compared to $T_{\mathrm{j}}$ (43\% compared to $29 \%$ ). Lastly, the dispersion mean for schooling $\left(E_{\mathrm{d}}\right)$ was acquired by comparing the respondents' schooling with the all employees' schooling in a particular firm. The variable was included to ascertain the extent to which differences in the education level of respondents with the workplace schooling affect individual wages ${ }^{3}$ (only taking into account the absolute value and ignoring the negative sign.)

Table 2: Colleagues' characteristics at workplace according to gender (mean and standard deviation)

\begin{tabular}{|c|c|c|c|c|c|c|}
\hline \multirow[b]{2}{*}{ Variable } & \multicolumn{2}{|c|}{ All } & \multicolumn{2}{|c|}{ Male } & \multicolumn{2}{|c|}{ Female } \\
\hline & Mean & $\begin{array}{c}\text { Stand } \\
\text { ard } \\
\text { deviat } \\
\text { ion }\end{array}$ & Mean & $\begin{array}{c}\text { Stand } \\
\text { ard } \\
\text { deviat } \\
\text { ion }\end{array}$ & Mean & $\begin{array}{c}\text { Stand } \\
\text { ard } \\
\text { deviat } \\
\text { ion }\end{array}$ \\
\hline \multicolumn{7}{|l|}{ Survey on respondents $\left(\mathrm{HC}_{\mathrm{r}}\right)$} \\
\hline Mean schooling period for all respondents for every firm $\left(E_{\mathrm{r}}\right)$ & 13.260 & 2.082 & 12.994 & 2.243 & 13.524 & 1.873 \\
\hline $\begin{array}{l}\text { Mean working experience for all respondents for every firm } \\
\left(\operatorname{Exp}_{\mathrm{r}}\right)\end{array}$ & 14.460 & 6.230 & 15.223 & 6.520 & 13.650 & 5.830 \\
\hline $\begin{array}{l}\text { Quadratic Mean for working experience of all respondents } \\
\text { for every firm }\left(\operatorname{Exp}_{\mathrm{r}}^{2}\right)\end{array}$ & 209.10 & 204.72 & 232.04 & 223.00 & 186.32 & 180.91 \\
\hline $\begin{array}{l}\text { Mean percentage of respondents' involvement in training for } \\
\text { every firm }\left(T_{\mathrm{r}}\right)\end{array}$ & 0.426 & 0.367 & 0.399 & 0.378 & 0.453 & 0.354 \\
\hline \multicolumn{7}{|l|}{ Survey on employers $\left(H C_{j}\right)$} \\
\hline Mean education for all employees at workplace $\left(E_{\mathrm{j}}\right)$ & 13.488 & 2.084 & 13.449 & 2.062 & 13.527 & 2.107 \\
\hline Mean age of all workers for every firm $\left(A g e_{\mathrm{j}}\right)$ & 34.964 & 5.157 & 35.259 & 5.173 & 34.671 & 5.126 \\
\hline Mean quadratic age for every workers in every firm $\left(A g e_{j}^{2}\right)$ & $\begin{array}{c}1249.0 \\
6\end{array}$ & 365.72 & $\begin{array}{c}1269.9 \\
4\end{array}$ & 368.68 & $\begin{array}{c}1228.3 \\
1\end{array}$ & 361.72 \\
\hline Mean percentage of workers' involvement in training for & 0.295 & 0.387 & 0.276 & 0.391 & 0.313 & 0.383 \\
\hline
\end{tabular}

\footnotetext{
2 It has to be stated that in the employers' survey, there was no information regarding the workers' overall work experience at the workplace. As such, the mean age for each worker at the workplace was used as proxy for colleagues' working experience as the age variable was used widely for studies related to human capital and individual wages. (Schafgans, 2000; Rumberger, 2008; Becker, 2009; Rahmah Ismail, 2011; Wail et al., 2011).

${ }^{3} S_{\mathrm{d}}$ only takes into consideration the absolute value and ignores the negative symbol.
} 
every firm $\left(T_{\mathrm{j}}\right)$

\section{Survey on employers and respondents}

Dispersed mean of respondents' and workers' schooling for every firm $\left(E_{\mathrm{d}}\right)$

\section{$\begin{array}{llllll}2.346 & 2.249 & 2.480 & 2.337 & 2.213 & 2.150\end{array}$}

Meanwhile, the effect of colleagues' human capital on individual wages can be estimated using the equation (1) below which was adapted from Mincer (1974), Idson and Kahane (2000) and Battu et al. (2004):

$$
\ln \left(w_{i j}\right)=\alpha_{0}+\beta H C_{i j}+\tau H C_{r j}+\delta H C_{j}+\gamma E_{d}+\varphi Z_{i j}+\varepsilon_{i j}
$$

where $w_{\mathrm{i}}$ refers to wage (monthly) for individual $i$ at firm $j$ influenced by $H C_{i}$, i.e.- vector of individuals' human capital stocks (education, work experience and training), colleagues' human capital stocks at the workplace based on respondents' measurement $\left(H C_{\mathrm{r}}\right)$ and employers' measurement $\left(H C_{j}\right), E_{\mathrm{d}}$, i.e.- mean of schooling dispersion at workplace $j$ and $Z_{i}$ which stands for other controlled factors such as gender, ethnic group, region, job types, firm size and firm ownership) and $\varepsilon_{i}$, error term. The coefficient for parameters $\alpha, \beta, \tau, \delta$ and $\gamma$ was calculated using the least squares method. A different analysis was conducted for the overall sample and the male and female samples. It should be remembered that the vector for $H C_{\mathrm{r}}$ and $H C_{\mathrm{j}}$ in (1) are included separately to test the robustness of the effect of colleagues' human capital on $w_{\mathrm{i}}$.

The main problem for estimating (1) was that the data utilised was in a hierarchical form, whereby the respondents were grouped into a big unit according to the firm or workplace. This meant that the respondents from the same firm would have the same characteristics compared to the respondents from another firm. As not all of the characteristics could be measured empirically, there is a possibility that the error term, $\varepsilon$ might be correlating and it might not be independent. If this occurs, the usage of least squares method might result in a biased outcome in estimating the coefficient for parameter in (2).

The equation in (1) had been modified to overcome the problem:

$$
\ln \left(w_{i j}\right)=\alpha_{0}+\beta H C_{i j}+\tau H C_{r j}+\delta H C_{j}+\gamma E_{d}+\varphi Z_{i j}+\mu_{i j}
$$

Instead of assuming coefficient $\alpha_{0 i j}$ in equation (3) as constant, the coefficient had been assumed as random with $\lambda_{0}$ (without $i$ subscript). The intercepted value $(\alpha)$ for the individuals in the firm can be described as the following (Wooldridge, 2015)

$$
\lambda_{0 \mathrm{i}}=\lambda_{0}+e_{\mathrm{ij}} \mathrm{i}=1,2, \ldots . \mathrm{N}
$$

Whereby $e_{\mathrm{ij}}$ refers to the random error term with a null mean value and $\sigma_{e}^{2}$ variance. As all the PSP firms in PICS had been chosen randomly from 5 main industries, each firm had a mean value similarity for $\left(\lambda_{0}\right)$ and each individual's intercepted value was different for every firm as shown by the $e_{\mathrm{ij}}$ error term. 
By substituting equation (3) into equation (2), this produced

$$
\ln \left(w_{i j}\right)=\alpha \alpha_{0}+\beta H C_{i j}+\tau H C_{r j}+\delta H C_{j}+\gamma E_{d}+\varphi Z_{i j}+e_{i}+\mu_{i j}
$$

or

$$
\ln \left(w_{i j}\right)=\alpha \alpha_{0}+\beta H C_{i j}+\tau H C_{r j}+\delta H C_{j}+\gamma E_{d}+\varphi Z_{i j}+\varepsilon_{i j}
$$

whereby

$$
\varepsilon_{i j}=e_{i}+\mu_{i j}
$$

The term composite error in equation (5) consists of 2 main components. The first one is individual error component, $e_{\mathrm{i}}$ which differs independently intercepting the individual in and between firms, and secondly, the error component for individual and firm, $\mu_{\mathrm{ij}}$ whereby the error differs between firms but is assumed as constant for the individual in the same firm. The error structure as this one indicates a random effect model (usually used with panel data). The assumption below is an example of random effect model (Damodar \& Dawn, 2004):

$$
\begin{aligned}
& e_{i} \sim N\left(\mathrm{O}, \sigma_{e}^{2}\right) \\
& \mu_{i j} \sim N\left(\mathrm{O}, \sigma_{\mu}^{2}\right) \\
& E\left(e_{i} \mu_{i j}\right)=\mathrm{O} \quad E\left(e_{i} e_{l}\right)=\mathrm{O} \quad(i \neq l) \\
& E\left(\mu_{i j} \mu_{i s}\right)=E\left(\mu_{i j} \mu_{l j}\right)=E\left(\mu_{i j} \mu_{l s}\right)=\mathrm{O} \quad(j \neq s ; i \neq l)
\end{aligned}
$$

in which, the individual error components do not correlate among themselves and also do not auto-correlate across individuals and workplace. The effect from these assumption is that all error has its own variance like the one below:

$$
E\left(\varepsilon_{i j}\right)=0
$$

$\operatorname{Var}\left(\varepsilon_{i j}\right)=\sigma^{2}=\sigma_{e}^{2}+\sigma_{\mu}^{2}$

which shows that for any $j$ firm, the error for different individuals correlate due to the sharing of component $\lambda_{j}$. As such, the suitable estimator to be used to estimate the coefficient for the parameter in equation (5) is the Random Effect Estimator using the Generalised Least Square (GLS) with the STATA 13 software. Bear in mind that any firm characteristics which are not included in $Z_{\mathrm{j}}$ are assumed to be random and combined with error terms.

\section{Study Findings}

Table 4 presents the study findings with 4 model specifications tested to identify the extent of the influence of one's human capital and colleagues' human capital on $w_{\mathrm{i}}$ (will be discussed later). ${ }^{4}$ The diagnostic test on all KR regression models found that the model formed had

\footnotetext{
${ }^{4}$ It has to be informed that based on Wooden and Bora (1999), Battu et. al (2004), and Wald and Fang (2008), the Langrange Multiplier (LM) test by Breusch dan Pagan had been conducted to assess whether the KR assessment method was suitable to be used compared to KKDT. The LM test showed that the KR estimation was statistically significant at a meaningful level of 1 percent across the 4 specification models formed and this indicated that the KR estimation was more suitable to be used compared to KKDT estimation..
} 
heteroscedasticity ${ }^{5}$ problem and to overcome this, the standard deviation used was based on 'robust standard error' as stated by Battu et al. (2004), Wooldridge (2012) and Zakariya (2014b). The diagnostic test also showed that the model specifications assumed was free from multi-collinearity issues. ${ }^{6}$ Overall, $46 \%$ to $47 \%$ of the controlled factors $\left(R^{2}\right.$ _overall) in Model $1-4$ could explain the variation in $w_{\mathrm{i}}$ while $60 \%$ to $61 \%$ of the model specification error was influenced by un-measurable workplace characteristics or 'unobserved characteristics' (refer to $\rho$ value). In line with the study objectives, only two variables were discussed which were the individual human capital influence and the colleagues' human capital stock influence on $w_{\mathrm{i}}$ due to the limited space. ${ }^{7}$

In line with the assumption of the human capital theory, Model 1 to 4 showed that the individual human capital $\left(E_{\mathrm{i}}, \operatorname{Exp}_{\mathrm{i}}\right.$ and $\left.T_{\mathrm{i}}\right)$ was extremely significant in influencing the individual salary $\left(w_{\mathrm{i}}\right)$.Specifically, an increase of one year of schooling, $E_{\mathrm{i}}$, would increase $w_{\mathrm{i}}$ as much as $9\left(\mathrm{e}^{0.858}-1\right.$ in Model 2) to -10 percent $\left(\mathrm{e}^{0.949}-1\right.$ in Model 4) per year. ${ }^{8}$ Meanwhile, an increase of one year of work experience, $\operatorname{Exp}_{\mathrm{i}}$ would increase $w_{\mathrm{i}}$ as much as $4.1-4.4$ percent. The $\operatorname{Exp}_{\mathrm{i}}$ quadratic value which was significant and negative, showed that the premium wage $\operatorname{Exp}_{\mathrm{i}}$ increased at a decreasing rate when the working experience increased. The individuals who acquired training at the workplace, $T_{\mathrm{i}}$, received salary from 13.4 to $14.8 \%$ higher per year compared to those who did not. As a comparison, the human capital stock premium wage, especially in higher education for the service sector, was found to be as high as the wage in a few other Malaysian studies (Ragayah, 2005; Milanovic, 2006; Rahmah Ismail, 2011; Zakariya, 2014b). This could be due to the fact that the service sector was usually linked to having a higher human capital stock, as well as the existence of more skilled labour compared to the manufacturing sector which was a reflection of the salary received (Rahmah \& Ragayah, 2003; Zakariya, 2014a).

Table 4. Influence of colleagues' human capital on the individual wage $\left(w_{\mathrm{i}}\right)$

\begin{tabular}{lccccc}
\hline Yearly salary $(\mathbf{l o g})$ & Model 1 & Model 2 & Model 3 & Model 4 \\
\hline Individual Human Capital & & & & & \\
Mean for respondents' schooling $\left(E_{\mathrm{i}}\right)$ & $0.0890 * * *$ & $0.0858 * * *$ & $0.0870 * * *$ & $0.0949 * * *$ \\
Work experience $\left(E x p_{\mathrm{i}}\right)$ & $(0.0051)$ & $(0.0053)$ & $(0.0052)$ & $(0.0049)$ \\
& $0.0427 * * *$ & $0.0429 * * *$ & $0.041 * * *$ & $0.0437 * * *$ \\
Quadratic work experience $\left(E x p_{\mathrm{i}}^{2}\right)$ & $(0.0038)$ & $(0.0039)$ & $(0.0038)$ & $(0.0038)$ & $-0.0006 * * *$ \\
Training $\left(T_{\mathrm{i}}\right)$ & $-0.0006 * * *$ & $-0.0006 * * *$ & $-0.0005 * * *$ & -0.006 \\
\hline
\end{tabular}

\footnotetext{
5 STATA, heteroscedasticity was tested based on Breush-Pagan/Cook-Weisberg and the hettest and whitetest or imtest directions. In both tests, the estimation model had a heteroscedasticity problem. Nonetheless, the rvplot showed that the problem was not serious.

${ }^{6}$ The multicollinearity was based on Vector Inflation Factor (VIF) using the vif and collin command in STATA. The two tests showed that there was no existence of countable collinearity among the independent variables.

${ }^{7}$ Factors such as demographic background, job attributes and workplace characteristics were included into the 4 model specifications and the study findings were in line with a few other studies in Malaysia ( for example, see Schafgans, 1998; Rahmah \& Ragayah, 2003; Amin \& DaVanzo, 2004; Ragayah, 2005; Milanovic, 2006; Rahmah, 2011; Zakariya, 2014a).

${ }^{8}$ As the wage regression specifications applied in this thesis were in the form of semi-logarithm, the percentage point effect (PE) method was used to ascertain the parameter coefficient value (Mincer, 1974; Becker, 2009). The PE value was obtained using the formula below : $\mathrm{PE}=\left(\mathrm{e}^{\beta}-1\right) \times 100$, where $\beta$ would be the coefficient estimated. The PE value would be used throughout the discussion of the study findings.
} 


$\begin{array}{llll}(0.0235) & (0.0254) & (0.0237) & (0.0237)\end{array}$

Characteristics of respondents' colleague data

Mean for colleagues' $\left(E_{\mathrm{r}}\right)$

$$
0.0379 * * *
$$

Respondents' overall working experience for each workplace $\left(\operatorname{Exp}_{\mathrm{r}}\right)$

0.0199

$(0.0439)$

Respondents' overall quadratic working experience for each workplace $\left(A g e_{r}^{2}\right)$

$-0.0002$

(0.0006)

Percentage of colleagues' training $\left(T_{\mathrm{r}}\right)$

$-0.0774$

$(0.0676)$

\section{Characteristics of colleagues' firm data}

Mean for colleagues' schooling at workplace $\left(E_{\mathrm{j}}\right)$

Age of colleagues at workplace $\left(A g e_{\mathrm{j}}\right)$

(0.0096)

$-0.0041$

(0.0411)

0.0000

Colleagues' quadratic age at workplace $\left(A g e^{2}{ }_{\mathrm{j}}\right)$

(0.0006)

0.1054

(0.0649)

\section{Dispersed mean for schooling}

Dispersed mean for schooling at workplace $\left(E_{\mathrm{d}}\right)$

0.0279

(0.0059)

Constant

$8.0706 * * * \quad 7.2416 * * * \quad 7.7789 * * * \quad 7.9081 * * *$

$\mathbf{N}$

$\begin{array}{llll}(0.2033) & (0.7999) & (0.7394) & (0.2092)\end{array}$

Number of firms

2,647

\section{2,647}

2,527

2,557

$\mathrm{R}^{2}$ _overall

265

265

253

256

$\mathrm{R}^{2}$ between

0.3808

0.3963

0.3922

0.4016

$\mathrm{R}^{2}$ within

0.4417

0.5082

0.4604

0.5096

Rho $(\rho)$

0.3151

0.2894

0.3173

0.3001

LM test

0.6357

0.5877

0.6367

0.5898

$1613.0 * * *$

$1600.1 * * *$

$1505.8 * * *$

Robust standard error in bracket

$*, * *$ and $* * *$ respectively significant at $0.1,0.05$ and 0.01

Note: Other controlled variables - demographic factors (gender, ethnic group, marital status and number of children, region), job characteristics (job type, number of working hours, member of labour union) and firm attributes (firm size, ownership, firm age). 


\section{Macrothink}

Model 2 measured the effect of colleagues' human capital on $w_{\mathrm{i}}$ based on respondents' data. From the table, we can see that the coefficient value for colleagues' education, $E_{\mathrm{r}}$, at 0.0379 was positive and significant at a meaningful level of 0.01, while the coefficients of $\operatorname{Exp}_{\mathrm{r}}$ and $T_{\mathrm{r}}$ were not significant. This showed that only $E_{\mathrm{r}}$ had a significant influence on $w_{\mathrm{i}}$. An increase of one year $E_{\mathrm{r}}$ could increase $w_{\mathrm{i}}$ as much as 3.8 percent $\left(\mathrm{e}^{0.379}-1\right)$ per year. As for Model 3 specifications, where the colleagues' variable was based on employer data and also the influence of colleagues' education at the workplace, only $E_{\mathrm{j}}$ was found to be significant in influencing $w_{\mathrm{i}}$ compared to $A g e_{\mathrm{j}}$ and $T_{\mathrm{j}}$. Nonetheless, the premium rate for $E_{\mathrm{j}}$ was lower compared to Model 2 at $2.8\left(\mathrm{e}^{0.0284}-1\right)$ percent per year for a year's increase in education at the workplace. Model 2 and 3 clearly showed that the colleagues' human capital stock, specifically concerning education, whether using respondents' measurement $\left(E_{\mathrm{r}}\right)$ or employers' measurement played an important part in increasing individual wages. In both models, the return rate was positive but small compared to $E_{\mathrm{i}}$ return rate. This clearly showed that there was a positive externality effect of colleagues' education on individual wages.

In Model 4, the influence of dispersed mean for schooling, $E_{\mathrm{d}}$ could be viewed positively to ascertain $w_{\mathrm{i}}$ with the coefficient value of 0.0279 and significant at a meaningful level of 0.01 . This could be described as an increase of one standard deviation point $E_{\mathrm{d}}$ could increase individual salary as much as 2.8 percent per year, which was the same as $E_{\mathrm{j}}$ premium rate (Model 3). This meant that the bigger the education gap between an individual and his/her colleague at the workplace, the higher the salary received. This is contrary to what was discussed previously ; however, this finding is in line with studies by Battu et al. (2003) in Britain (further discussion will be in the next section ).

Table 5: Influence of colleagues' human capital stock on individual salary ( $w_{\mathrm{i}}$ ) for male 


\section{Al Macrothink}

International Journal of Human Resource Studies

ISSN 2162-3058

2017, Vol. 7, No. 1

sample

\begin{tabular}{|c|c|c|c|c|c|c|c|c|}
\hline \multirow{2}{*}{ Monthly income log } & \multicolumn{4}{|c|}{ Male } & \multicolumn{4}{|c|}{ Female } \\
\hline & Model 1 & Model 2 & Model 3 & Model 4 & Model 1 & Model 2 & Model 3 & Model 4 \\
\hline \multicolumn{9}{|l|}{ Individuals' Human capital stocks } \\
\hline \multirow[t]{2}{*}{ Mean for respondents' schooling $\left(\mathrm{E}_{\mathrm{i}}\right)$} & $0.1048 * * *$ & $0.1002 * * *$ & $0.1028 * * *$ & $0.1149 * * *$ & $0.0789 * * *$ & $0.0727 * * *$ & $0.0773 * * *$ & $0.0821 * * *$ \\
\hline & $(0.0074)$ & $(0.0078)$ & $(0.0075)$ & $(0.0073)$ & $(0.0074)$ & $(0.0076)$ & $(0.0076)$ & $(0.0070)$ \\
\hline Working experience $\left(\operatorname{Exp}_{\mathrm{i}}\right)$ & $(0.0058)$ & $(0.0059)$ & $(0.0057)$ & $(0.0057)$ & $(0.0053)$ & $(0.0053)$ & $(0.0055)$ & $(0.0053)$ \\
\hline \multirow[t]{2}{*}{ Quadratic working experience $\left(\operatorname{Exp}^{2}{ }_{\mathrm{i}}^{2}\right.$} & $-0.0006 * * *$ & $-0.0006 * * *$ & $-0.0005 * * *$ & $-0.0007 * * *$ & $-0.0009 * * *$ & $-0.0009 * * *$ & $-0.0009 * * *$ & $-0.0010 * * *$ \\
\hline & $(0.0001)$ & $(0.0001)$ & $(0.0001)$ & $(0.0001)$ & $(0.0001)$ & $(0.0001)$ & $(0.0001)$ & $(0.0001)$ \\
\hline \multirow[t]{2}{*}{ Training $\left(\mathrm{T}_{\mathrm{i}}\right)$} & $0.1200 * * *$ & $0.1477 * * *$ & $0.1051 * * *$ & $0.1068 * * *$ & $0.1431 * * *$ & $0.1405 * * *$ & $0.1455 * * *$ & $0.1475 * * *$ \\
\hline & $(0.0345)$ & $(0.0389)$ & $(0.0349)$ & $(0.0347)$ & $(0.0305)$ & $(0.0343)$ & $(0.0309)$ & $(0.0305)$ \\
\hline \multirow[t]{4}{*}{ Mean for colleagues' schooling $\left(\mathrm{E}_{\mathrm{r}}\right)$} & & $0.0354 * *$ & & & & $0.0463 * * *$ & & \\
\hline & & $(0.0173)$ & & & & $(0.0139)$ & & \\
\hline & & -0.0204 & & & & 0.0272 & & \\
\hline & & $(0.0575)$ & & & & $(0.0445)$ & & \\
\hline \multicolumn{9}{|c|}{ Respondents' quadratic working experience } \\
\hline for every workplace $\left(\operatorname{Exp}_{r}^{2}\right)$ & & $(0.0008)$ & & & & $(0.0006)$ & & \\
\hline \multirow[t]{2}{*}{ Percentage of colleagues' training $\left(T_{\mathrm{r}}\right)$} & & $-0.1572 *$ & & & & 0.0129 & & \\
\hline & & $(0.0893)$ & & & & $(0.0746)$ & & \\
\hline
\end{tabular}

\section{Characteristics of colleagues' firm data}

Mean for colleagues' schooling at workplace

$\left(E_{\mathrm{j}}\right)$

$\begin{array}{lc}0.0302 * * & 0.0252 * * * \\ (0.0121) & (0.0093) \\ -0.0083 & -0.0026 \\ (0.0523) & (0.0408) \\ 0.0000 & 0.0000 \\ (0.0007) & (0.0006) \\ 0.1237 & 0.0705 \\ (0.0852) & (0.0537)\end{array}$

\section{Dispersed mean for schooling}

Dispersed mean for schooling at workplace

$\left(E_{\mathrm{d}}\right)$

$0.0366 * * *$

$0.0199 * * *$

(0.0084)

(0.0077)

Constant

$7.4982 * * * \quad 7.8938 * * * \quad 6.9259 * * * \quad 7.7211 * * * \quad 7.8079 * * *$

$\begin{array}{lllllllll}(0.3092) & (1.1025) & (0.9808) & (0.3068) & (0.2338) & (0.7887) & (0.7292) & (0.2462)\end{array}$

$\mathbf{N}$

$1,319 \quad 1,319 \quad 1,261$

$1,276 \quad 1,328$

1,328

1,266

1,281

Number of firm

259

$259 \quad 247$

$250 \quad 260$

$260 \quad 248$

251 


\begin{tabular}{lcllllllrrr}
\hline $\mathrm{R}^{2}$ _overall & 0.3816 & 0.3906 & 0.3914 & 0.3929 & 0.4135 & 0.4305 & 0.4257 & 0.4188 \\
$\mathrm{R}^{2}$ between & 0.3992 & 0.4146 & 0.4065 & 0.4036 & 0.4356 & 0.4666 & 0.454 & 0.437 \\
$\mathrm{R}^{2}$ within & 0.3518 & 0.3529 & 0.3598 & 0.3614 & 0.3152 & 0.3151 & 0.3182 & 0.32 \\
Rho $(\rho)$ & 0.6478 & 0.6457 & 0.6542 & 0.6498 & 0.6035 & 0.5843 & 0.6048 & 0.6093 \\
LM test & $683.1 * * *$ & $676.8^{* * *}$ & $647.2 * * *$ & $615.6 * * *$ & $300.9 * * *$ & $265.3 * * *$ & $271.9 * * *$ & $294.7 * * *$ \\
\hline
\end{tabular}

Robust standard error in bracket

$*, * *$ and $* * *$ respectively significant at $0.1,0.05$ and 0.01

Note: Other controlled variables - demographic factors (gender, ethnic group, marital status and number of children, region), job characteristics (job type, number of working hours, member of labour union) and firm attributes (firm size, ownership, firm age).

Table 5 discusses the extent of the influence of individual and colleagues' human capital on one's own salary separately according to respondents' gender as the descriptive analysis in Table 1 and 2 revealed that colleagues' human capital stock differed according to respondents' gender. Thus, it is possible that the different characteristics could provide a different effect in terms of magnitude for male and female. In fact, there are a few studies which suggested that female workers prefer to work individually compared to male workers (Santhapparaj, Srineevasan, \& King, 2005; Lew \& Liew, 2006; Wong \& Heng, 2009; Alam \& Mohammad, 2010). From the table, about $38 \%$ to $39 \%$ and $41 \%$ to $43 \%$ variation in the respective $w_{\mathrm{i}}$ for male and female could be explained by controlled factors $\left(R^{2}\right.$ overall) and the rest controlled by other factors (error). From the value, $58-65 \%$ in the error was influenced by unmeasurable firm characteristics $(\rho)$. The $\rho$ value appeared slightly higher for the male sample. Once more the LM test for both samples suggested that the KR estimate was more suitable compared to KKDT as the former took into account firm characteristics which were not included in the model.

From Table 5, we find that the three human capital stocks $E_{\mathrm{i}}, \operatorname{Exp}_{\mathrm{i}}$ and $T_{\mathrm{i}}$ were positive and significant in influencing one's salary, $w_{\mathrm{i}} .{ }^{9}$ Nonetheless, the premium rate for the three human capital stocks differed slightly according to the sample. The premium rate for $E_{\mathrm{i}}$ was 2 to 4 percentage points higher for the male sample compared to the female sample. An increase of one year of individual schooling $\left(E_{\mathrm{i}}\right)$ would increase $w_{\mathrm{i}}$ between $10.5\left(\mathrm{e}^{0.1002}-1\right)$ to $12.2\left(\mathrm{e}^{0.1149}-1\right)$ percent annually for male workers and between $7.5\left(\mathrm{e}^{0.0727}-1\right)$ to $8.2\left(\mathrm{e}^{0.821}\right.$ - 1) percent for female workers. On the other hand, the return rate for $\operatorname{Exp}_{\mathrm{i}}$ appeared to be almost similar for both the male and female samples, from 4.8 to 5 percent annually. As for $T_{\mathrm{i}}$, it was found that female workers received a premium wage of $2-4$ percent higher or $14-$ $16 \%$ compared to $11-13 \%$ for the male workers

Moving on to Model 2 and 3, Table 5 shows that the influence of the colleagues' human capital depended on the human capital type specifications. For $E_{\mathrm{r}}$, the influence of colleagues' education on $w_{\mathrm{i}}$ was significant for both samples and the return rate was slightly higher for the female sample compared to the male sample. In the case of Model 2, the premium wage

\footnotetext{
${ }^{9}$ Perlu dimaklumkan bahawa regresi penganggaran upah mengawal semua faktor-faktor latar belakang demografi, atribut pekerjaan dan karakter tempat kerja. Namun bahagian ini membincangkan hanya pengaruh modal manusia individu dan rakan sekerja mereka ke atas upah disebabkan ruangan yang terhad.
} 
$E_{\mathrm{r}}$ was 4.7 percent for females and 3.5 percent for males. On the other hand, for Model 3, the premium wage $E_{\mathrm{j}}$ was slightly higher for males compared tp female ( 3 vs 2.5 percent). For colleagues' working experience $\operatorname{Exp}_{\mathrm{r}}$ (Model 2) and $A g e_{\mathrm{j}}$ (Model 3), no influence could be ascertained for these two samples. The influence of colleagues' training on $w_{\mathrm{i}}$ appeared to be inconsistent as it was only significant in the case of Model $2\left(T_{\mathrm{r}}\right)$ for males only. Surprisingly, $T_{\mathrm{r}}$ had a negative influence on $w_{\mathrm{i}}$ with a value of -0.1572 , even though it was significant at a meaningful level of 0.1 . In the case of Model 4 , the variable $E_{\mathrm{d}}$ was positive and significant for both male and female samples. This finding was in line with the general sample, and the premium rate $E_{\mathrm{d}}$ was higher for the male sample with 3.7 percent, compared to 2 percent for the female sample.

\section{Discussions and Conclusions}

The study findings above show that the accumulation of individual human capital stock such as $E_{\mathrm{i}}, \operatorname{Exp}_{\mathrm{i} \text { and }} T_{\mathrm{i}}$ play an important role in upgrading the individual productivity through an increase in $\left(w_{\mathrm{i}}\right)$. These findings were consistent for the general sample, the male sample and the female sample. This situation is not surprising as the human capital theory states that the worker's individual productivity (salary) is dependent on the human capital accumulation. An increase in individual education and work experience as well as involvement in training during the working period would provide a positive effect on the salary received. The return rate in education acquired of about 8 to $11 \%$ was in line with a few other studies in Malaysia (Rahmah \& Zin, 2003; Rahmah \& Noor, 2005; Milanovic, 2006; Rahmah, 2011; Wail et al., 2011; Zakariya, 2014a).

However, the human capital theory does not discuss the influence of colleagues' human capital at the workplace. In the challenging workplace, the worker does not do things on his own as he needs other workmates in implementing a particular task. If the human capital provides a positive effect on an individual's productivity, this indirectly causes a positive productivity spillover on other colleagues at the workplace. This study later revealed that colleagues' human capital (specifically colleagues' education) had a positive and significant effect on individual salary or productivity. Clearly, the influence of colleagues' education on $w_{\mathrm{i}}$ was consistent (robust) whether $E_{\mathrm{r} \text { or }} E_{\mathrm{j}}$ was utilised. This was consistent for the general sample, the male sample and the female sample. However, the colleagues' premium salary appeared higher for Model $2\left(E_{\mathrm{r}}\right)$ compared to Model $3\left(E_{\mathrm{j}}\right)$.

The positive effect of colleagues' education on individual salary could be translated into the existence of positive externality or spillover at the workplace which could increase the productivity of other workers in the same organisation. This probably occurs due to the sharing of information, skills and knowledge among the workers - the strong would help the weak and the skilled would help the less skilled, as well as the workers' spirit of cooperation. In this way, the knowledge and skills acquired could be used by the workers for other tasks, without having to attend other courses, like what has been discussed in previous studies (Idson, 1995; Idson \& Kahane, 2000; Moretti, 2004; Fu, 2007; Rosenthal \& Strange, 2008; Ramos, Suriñach, \& Artís, 2010). Perhaps it is not too much to state that the colleagues' education may possibly complement the individual's existing education. This may occur as 
the premium rate for education $E_{\mathrm{i}}$, was still high and had not gone through many changes even though the colleagues' human capital covariate had been included in the estimation model. Combining knowledge acquired through one's education with the knowledge acquired from colleagues' education would make an individual more productive in doing his daily duties.

Lastly, the influence of $E_{\mathrm{d}}$, which is the dispersed mean for schooling, $E_{\mathrm{i}}$ and workplace schooling on individual productivity as discussed in Model 4 was positive and significant for the overall sample and gender sub-sample. The bigger the gap between $E_{\mathrm{d}}$ and $E_{\mathrm{i}}$ (absolute value), the higher the premium salary received which was between 2.6 to 3.2 percent. The premium salary rate was also higher for the male sample compared to the female sample. However, this finding seems to contradict the 'O-ring' theory (Kremer, 1993) which stated that workers with advanced education would be more productive at the workplace if they had workmates with equal advanced qualifications( where the $E_{\mathrm{d}}$ gap had narrowed). This finding might indicate that the individual education $E_{\mathrm{i}}$ was lower than colleagues' education, $E_{\mathrm{r}}$ or $E_{\mathrm{j}}$, and the positive effect could be felt by the individual himself. In actual fact, Table 1 and 2 did not show an obvious gap between individual education with colleagues' education.

Unlike education, other colleagues' human capital influences such as working experience and training were seen as not significant on individual salary and this finding was consistent for all samples analysed (using either respondents' measurement or employers' measurement). This differs from the finding for individual's working experience, $\operatorname{Exp}_{\mathrm{i}}$ and $T_{\mathrm{i}}$. This difference might be due to different measurements, especially in the case of colleagues' working experience as the proxy to the variable was based on the mean age of all the respondents at the workplace and not their real working experience.

Based on the discussion above, the government's move to upgrade the quality of labour in Malaysia as well as enable the public, especially students to gain access to higher education to increase the production of graduates (as outlined in the NKRA program) is indeed a step in the right direction. This is because individuals who are educated, knowledgeable and skilled are not only productive, but they are also able to disseminate and share their knowledge and skills with other people around them, including their colleagues, in the form of externality effect or education social return.

\section{Acknowledgement}

We would like to thank The World Bank Enterprise Survey (WBES) for allowing the use of the Productivity and Investment Climate Survey (PICS) data in this study. The study was partly made possible with funding from the Fundamental Research Grant Scheme (FRGS) (Project code: 2014-0028-106-02). Both parties are not responsible for the authors' analysis, views and interpretation in the study.

\section{References}

Acemoglu, D., \& Angrist, J. (2001). How large are human-capital externalities? Evidence from compulsory-schooling laws. In NBER Macroeconomics Annual 2000, Volume 15 (pp. 9-74). MIT Press. 
Alam, M. M., \& Mohammad, J. F. (2010). Level of job satisfaction and intent to leave among Malaysian nurses. Business Intelligence Journal, 3(1), 123-137. Retrieved from http://www.iiuedu.org/images/pdf/BIJ-Vol3No1 January 2010.pdf\#page=125

Amin, S., \& DaVanzo, J. (2004). The impact of wives' earnings on earnings inequality among married-couple households in Malaysia. Journal of Asian Economics, 15(1), 49-70. http://doi.org/10.1016/j.asieco.2003.12.002

Bandiera, O., Barankay, I., \& Rasul, I. (2013). Team incentives: Evidence from a firm level experiment. Journal of the European Economic Association, 11(5), 1079-1114.

Barron, J. M., Berger, M. C., \& Black, D. A. (1999). Do workers pay for on-the-job training? Journal of Human Resources, 235-252.

Battu, H., Belfield, C. R., \& Sloane, P. J. (2004). Human capital spillovers in the workplace: evidence for the service sector in Britain. International Journal of Manpower, 25(1), 123-138. http://doi.org/10.1108/01437720410525036

Battu, H., Belfield, C., \& Sloane, P. (2003). Human Capital Spillovers within the Workplace: Evidence for Great Britain*. Oxford Bulletin of Economics ..., 65(5), 0575-0594. Retrieved from http://onlinelibrary.wiley.com/doi/10.1111/j.1468-0084.2003.00062.x/full

Becker, G. S. (1962). Investment in human capital: A theoretical analysis. The Journal of Political Economy, 9-49.

Becker, G. S. (2009). Human capital: A theoretical and empirical analysis, with special reference to education. Chicago: University of Chicago Press.

Behrman, J. R., \& Stacey, N. (1997). The social benefits of education. University of Michigan Press.

Bennell, P. (1998). Rates of Return to Eduation in Asia: A Review of the Evidence. Education Economics, 6(2), 107-120. http://doi.org/10.1080/09645299800000010

Charness, G., \& Kuhn, P. (2004). Do Co-Workers' Wages Matter?: Theory and Evidence on Wage Secrecy, Wage Compression and Effort. No. 1417. IZA Discussion Paper Series, 2004., 1417. Retrieved from http://www.econstor.eu/handle/10419/20715

Chung, T. (2003). Returns to education: updates for Malaysia. Applied Economics Letters, 10(13), 837-841. http://doi.org/10.1080/1350485032000138926

Chung, T. (2004). The returns to education over time: The Malaysian outlook, 1984-1997. In 4th International Malaysian Studies Conference, 3-5 August 2004 Universiti Kebangsaan Malaysia (pp. 1-29). Bangi: UKM. Retrieved from http://english.cpiasia.net/dmdocuments/The Returns to Education Over Time_The Malaysian Outlook, 1984-1997.pdf

Damodar, G., \& Dawn, C. P. (2004). Econometr\{í\}a. Editorial Mac Graw Hill,.

Fu, S. (2007). Smart Café Cities: Testing human capital externalities in the Boston 
metropolitan area. Journal of Urban Economics, 61(1), 86-111. http://doi.org/10.1016/j.jue.2006.06.002

Galegher, J., Kraut, R. E., \& Egido, C. (2014). Intellectual teamwork: Social and technological foundations of cooperative work. Psychology Press.

Idson, T. (1995). Team production effects on earnings. Economics Letters, (675), 23-45. Retrieved from http://www.sciencedirect.com/science/article/pii/0165176595006675

Idson, T., \& Kahane, L. (2000). Team effects on compensation: an application to salary determination in the National Hockey League. Economic Inquiry, 38(2), 345-357. Retrieved from http://onlinelibrary.wiley.com/doi/10.1111/j.1465-7295.2000.tb00022.x/full

Isacsson, G. (2005). External effects of education on earnings: Swedish evidence using matched employee-establishment data. Working Paper 2005:10, 1-42. Retrieved from http://www.econstor.eu/handle/10419/78626

Kirby, S., \& Riley, R. (2008). The external returns to education: UK evidence using repeated cross-sections. Labour Economics, 619-630. http://doi.org/10.1016/j.labeco.2008.04.004

Kremer, M. (1993). The O-ring theory of economic development. The Quarterly Journal of Economics, 551-575.

Lew, T. Y., \& Liew, M. Y. (2006). Exploring the antecedents of needs and job satisfaction among employees of a leading bank in Malaysia: Implications for managing bank employees in Malaysia. Banker sournal Malaysia, 29(1), 10-26.

Li, C., Gervais, G., Duval, A., Houle, C., \& Soucy, D. (2006). Analysis in Brief The Dynamics of Overqualification : Canada's Underemployed University Graduates, (11), 1-18.

Liu, Z. (2007). The external returns to education: Evidence from Chinese cities. Journal of Urban Economics, 61(3), 542-564. http://doi.org/10.1016/j.jue.2006.08.007

Mazumdar, D. (1993). Labor Markets and Adjustment in Open Asian Economies: The Republic of Korea and Malaysia. The World Bank Economic Review, 7(3), 349-380. http://doi.org/10.1093/wber/7.3.349

Milanovic, B. (2006). Inequality and Determinants of Earnings in Malaysia, 1984-1997. Asian Economic Journal, 20(2), 191-216. http://doi.org/10.1111/j.1467-8381.2006.00230.x

Mincer, J. (1974a). Schooling, Experience, and Earnings.

Mincer, J. (1974b). Schooling, Experience, and Earnings (No. No. 2).

Moretti, E. (2004a). Estimating the social return to higher education: Evidence from longitudinal and repeated cross-sectional data. Journal of Econometrics, 121(1-2), 175-212. http://doi.org/10.1016/j.jeconom.2003.10.015

Moretti, E. (2004b). Human capital externalities in cities. Handbook of Regional and Urban Economics, 4(April), 2243-2291. Retrieved from 
http://www.sciencedirect.com/science/article/pii/S1574008004800087

Moretti, E. (2004c). Workers' education, spillovers, and productivity: evidence from plant-level production functions. American Economic Review, 94(3), 656-690. Retrieved from http://www.jstor.org/stable/3592947

Munch, J. R., \& Skaksen, J. R. (2008). Human capital and wages in exporting firms. Journal of International Economics, 75(2), 363-372. http://doi.org/10.1016/j.jinteco.2008.02.006

Psacharopoulos, G. (1993). Returns to Investment in Education: A Global Update.

Psacharopoulos, G., \& Patrinos *, H. A. (2004). Returns to investment in education: a further update. Education Economics, 12(2), 111-134. http://doi.org/10.1080/0964529042000239140

Ragayah, H. M. Z. (2005). Income distribution in East Asian developing countries: recent trends. Asian-Pacific Economic Literature, 19(2), 36-54. Retrieved from http://onlinelibrary.wiley.com/doi/10.1111/j.1467-8411.2005.00167.x/full

Rahmah, I. (2011). Gender wage differentials in the Malaysian services sector. African Journal of Business Management, 5(19), 7781-7789. http://doi.org/10.5897/AJBM10.047

Rahmah, I. Ragayah, Z., \& Noor, Z. (2005). Gender wage differentials in the Malaysian manufacturing sector. International Journal of Economics and Management, 2(2), 119-137. Retrieved from http://journals.iium.edu.my/enmjournal/index.php/enmj/article/view/110

Rahmah, I., \& Ragayah, Zin. (2003). Earnings differentials determinants between skills in the Malaysian manufacturing sector. Asian Economic Journal, 17(4), 325-340. Retrieved from http://onlinelibrary.wiley.com/doi/10.1111/j.1467-8381.2003.00189.x/abstract

Ramos, R., Suriñach, J., \& Artís, M. (2010). Human capital spillovers, productivity and regional convergence in Spain. Papers in Regional Science, 89(2), 435-447. http://doi.org/10.1111/j.1435-5957.2010.00296.x

Rauch, J. E. (1993). Productivity gains from geographic concentration of human capital: evidence from the cities. Journal of Urban Economics, 34(3), 380-400.

Rosenthal, S. S., \& Strange, W. C. (2008a). The attenuation of human capital spillovers. Journal of Urban Economics, 64(2), 373-389. http://doi.org/10.1016/j.jue.2008.02.006

Rosenthal, S. S., \& Strange, W. C. (2008b). The attenuation of human capital spillovers. Journal of Urban Economics, 64, 373-389. http://doi.org/10.1016/j.jue.2008.02.006

Rumberger, R. W. (2008). The Impact of Surplus Schooling on Productivity and Earnings, 22(1), 24-50.

Sand, B. M. (2013). A re-examination of the social returns to education: Evidence from U.S. cities. Labour Economics, 24, 97-106. http://doi.org/10.1016/j.labeco.2013.07.001

Santhapparaj, A. S., Srineevasan, J., \& King, K. L. (2005). Job satisfaction among women managers in Malaysian automobile manufacturing sector. Journal of Applied Science, 5(9), $153-158$. 
Schafgans, M. M. A. (1998). ETHNIC WAGE DIFFERENCES IN MALAYSIA: PARAMETRIC AND SEMIPARAMETRIC ESTIMATION OF THE CHINESE-MALAY WAGE GAP. Journal of Applied Econometrics, 504(May), 481-504.

Schafgans, M. M. A. (2000). Gender wage differences in Malaysia: parametric and semiparametric estimation. Journal of Development Economics, 63, 351-387.

Schaubroeck, J., Lam, S. S. K., \& Peng, A. C. (2011). Cognition-based and affect-based trust as mediators of leader behavior influences on team performance. Journal of Applied Psychology, 96(4), 863.

Wail, N., Ismail, R., \& Yussof, I. (2011). Analisis Penentu Perbezaan Upah Mengikut Kemahiran di Malaysia. Sains Humanika, 56(Sept), 1-22. Retrieved from http://www.sainshumanika.utm.my/index.php/sainshumanika/article/view/223

Wald, S., \& Fang, T. (2008). Overeducated immigrants in the Canadian labour market: Evidence from the workplace and employee survey. Canadian Public Policy, 34(4), 457-479.

Wong, E. S. K., \& Heng, T. N. (2009). Case study of factors influencing jobs satisfaction in two Malaysian universities. International Business Research, 2(2), p86.

Wooden, M., \& Bora, B. (1999). Workplace characteristics and their effects on wages: Australian evidence. Australian Economic Papers, 38(3), 276-289.

Wooldridge, J. (2012). Introductory econometrics: A modern approach. Cengage Learning.

Wooldridge, J. (2015). Introductory econometrics: A modern approach. Nelson Education.

Zakariya, Z. (2013). Returns to Education: What Roles Do Over, Required and Under-education Play? In Prosiding PERKEM IV, JILID 1 (Vol. 1, pp. 266-278). Johor Baharu: Universiti Kebangsaan Malaysia.

Zakariya, Z. (2014a). The Effects of Over, Required and Under-Education on Earnings in Manufacturing Sector in Malaysia. International Journal of Management Studies, 21(1), 83-109.

Zakariya, Z. (2014b). Wage effect of over-education and mismatch in Malaysia: a random effect approach. Jurnal Ekonomi Malaysia, 48(2), 3-17. Retrieved from http://journalarticle.ukm.my/8508/

\section{Copyright Disclaimer}

Copyright for this article is retained by the author(s), with first publication rights granted to the journal.

This is an open-access article distributed under the terms and conditions of the Creative Commons Attribution license (http://creativecommons.org/licenses/by/3.0/). 